\section{IJ§ER}

ISSN: 2149-5939
International Journal of Social Sciences and Education Research

Online, http://dergipark.gov.tr/ijsser

Volume: 3(1), 2017

\title{
Öğretmen adaylarının çocuk haklarına yönelik tutumları
}

\author{
Prospective teachers' attitudes towards children rights
}

\author{
Hatice Leblebici $^{1} \quad$ Nadir Çeliköz ${ }^{2}$
}

Received Date: 07 / 09 / 2016

Accepted Date: $25 / 12$ / 2016

\section{$\ddot{O} z$}

Bu araștırmanın genel amacı ögretmen adaylarının çocuk haklarına yönelik tutumlarını ve bu tutumlar üzerinde etkili olabilecek bazı faktörleri belirlemektir. Tarama modelinin kullanıldı ğı araştırmanın örneklemini Istanbul'da biri devlet diğeri vakıf üniversitesi olmak üzere iki farklı üniversitenin eğitim fakültelerinin okul öncesi (119) ve sinıf ögrretmenliği (137) bölümlerinde öğrenim gören toplam 256 ögretmen adayı oluşturmaktadır. Araştırmanın verileri Karaman Kepenekçi (2006) tarafindan geliştirilen 'Çocuk Haklarına Yönelik Tutum Ölçeği' kullanılarak toplanmıştır. Veri toplama aracının geçerlilik-güvenirlik çalışmaları Karaman Kepenekçi (2006) tarafindan yapılmış olmakla birlikte bu araştırmada ayrıca DFA (doğrulayıcı faktör analizi) ve Cronbach Alpha güvenirlik çalışmaları yapılarak, daha geçerli ve daha güvenilir veriler elde edilmeye çalışılmıştır. Elde edilen sonuçlar, ögretmen adaylarının çocuk haklarına yönelik genel tutumlarının oldukça yüksek düzeyde olumlu olduğunu ortaya koymuş̧ur. Öğretmen adaylarının sını öğretmenliği ya da okul öncesi öğretmenliği bölümlerinde öğrenim görüyor olmaları onların tutumlarını değiștirmezken, kadın ögretmen adaylarının erkeklere oranla tutumlarının daha olumlu olduğu bulunmuştur. Ayrıca aile ortamında 3 ya da daha fazla kardeşle birlikte yetişen öğretmen adaylarının kardeși bulunmayan ya da 3'ten az kardeșe sahip olan öğretmen adaylarından tutumlarının daha olumlu olduğu sonucuna ulaşılmıştır. Öğretmen adaylarının tutumları üzerinde etkili olan faktörlerden birisi de onların "çocuk hakları sözleşmesini” okuyup öğrenmiş olmalarıdır. Çocuk hakları sözleşmesini okuyan öğretmen adayları, okumayanlara göre çocuk haklarına yönelik daha olumlu tutum sergilemektedirler.

Anahtar Sözcükler: Öğretmen adayları, çocuk hakları, tutum

\begin{abstract}
The aim of the study is to idetify attitudes of prospective teachers towards children rights and investigate the factors which have impact on these attitudes. Participants were chosen with survey method among a sample of 256 teacher candidates from education faculties of one state and one foundation university composed of preschool teaching (119) and classroom teaching (137) programs. Data is collected with Karaman Kepenekci (2006) "Scale of Attitude Toward Child Rights". Reliability and validity measures were conducted by Karaman Kepenekci (2006) previously, and additional relability and validity ensured with confirmatory factor analysis and Cronbach Alpha test. Results revealed high levels of positive attitude of prospective teachers toward child rights. Although attitude was not predicted by the program of prospective teachers, female candidates were appeared to have more positive attitudes compared to male candidates. Prospective teachers raised with 3 or more siblings appeared to have more positive attitudes towards child rights compared to prospective teachers raised alone or with less than 3 siblings. One factor appeared to have a significant effect on attitudes of prospective teachers was having read the "child rights article". Prospective teachers who have read the Children Rights Article exhibited more positive attitude toward children rights, compared to prospective teachers who have not.
\end{abstract}

Keywords: Prospective teachers, children rights, attitude

\section{Giriş}

Eğitim, toplumun kültürünü yeni nesillere aktarırken, bireylerin toplumsallaştırılmasını da sağlamaktadır. Öğrenciler, okulda ders ve etkinlikler yoluyla toplumun milli, ahlaki değerlerini

\footnotetext{
${ }^{1}$ Sorumlu yazar, Yıldız Teknik Üniversitesi, İstanbul, Türkiye, leblebicih@gmail.com
}

${ }^{2}$ Doç. Dr., Yıldız Teknik Üniversitesi, İstanbul, Türkiye, ncelikoz@gmail.com 
Leblebici, H., Çeliköz, N. (2017). Öğretmen adaylarının çocuk haklarına yönelik tutumları. International Journal of Social Sciences and Education Research, 3(1), 307-318.

ve kurallarını kazanırken diğer yandan da çevreden aldıkları değer ve kurallara göre şekillenmektedirler (Erden, 2007). Demokratik değer, tutum ve davranışların geliştirilmesi, insanın özgürlüğü ile mutluluğu, toplumsal örgütleşme ve nitelikli vatandaşların yetiştirilmesi demokrasi ve insan hakları kültürü, bir devlet yönetim biçimi olduğu kadar toplum ve insan için de bir yaşam tarzıdır. Demokratik toplumlarda insan hakları temel alınmakta ve demokratik laik sosyal hukuk devleti temelinde her alanda insan odak noktası olmaktadır. Her alanda insanca yaşama ve gelişmenin temel amaç ve hedef olduğu, katılım, dayanışma ve paylaşmanın toplumsal bütünleşmeyi sağladığ sorumluluk sahibi ve bilinçli vatandaşların etkili olduğu bir toplum düşüncesini gerektirmektedir (Cılga, 2001). Eğitim birey ile birlikte toplumu da içine alan bir süreçtir. Bu sebeple demokrasi, insan hakları, çocuk hakları gibi temel unsurlara dayalı yetişen bireyler toplumun gelecek nesillere yönelik şekillenmesini de sağlamış olurlar. Çünkü; demokratik düşünme ve demokratik düşünceye uygun davranışlarda bulunmak, doğuştan gelen bir özellik olmayıp, bir eğitim sorunu niteliği taşımaktadır (Yeşil, 2002). Eğitimin, demokrasilerde çok özel bir konuma sahip olması gerekmekte; demokrasi için de, eğitim önemli bir yer tutmaktadır. Yine eğitim, demokratik bir toplum oluşturmanın ön şartı olarak kabul edilmekte, demokrasi ve insan haklarının güçlendirilmesinde en önemli sistemlerden birini oluşturarak, eğitim sisteminin de bireyleri bilinçlendirme sorumluluğu bulunmaktadır (Selvi, 2003).

Öğretmen, belirli bir program çerçevesinde planlı eğitim etkinlikleri düzenleyerek, öğrencilerde programlar doğrultusunda istendik davranış değişikliği meydana getirmektedir (Erden, 2007). Öğretmenlerin kişisel nitelikleri, çocuğun okula ve derse yönelik tutumlarını etkilemektedir (Erden, 2007). Demokratik tutuma sahip bir öğretmenin bulunduğu sınıf ortamı, öğrencinin özdenetim ve bireysel karar verme gibi becerilerinin gelişmesini sağlamaktadır (Ilgar, 2000). Demokratik tutumlara sahip olmayan bir öğretmenin öğrencilerinde demokratik davranışlar geliştirmesi mümkün olmayacaktır. Zaten demokrasiyi bir yaşam biçimi olarak özümsemiş bir öğretmenin, sınıf içerisindeki davranışlarının da demokratik olması beklenmektedir (Gözütok, 1995; Erden, 2007). Öğretmenlerin sınıf içerisinde veya dışında gösterdikleri davranış ve tutumlar öğrenciler üzerinde etkili olmaktadır. Demokratik bir toplum yapısının oluşturulması açısından öğretmenlerin bu değerlere sahip olma durumlarının incelenmesinin gerekliliği önem kazanmaktadır.

İkinci Dünya Savaşı'ndan sonra demokrasi, insan hakları, çocuk hakları gibi kavramlar ortaya çıkmış ve bu alanlarda hazırlanan bildiri ve sözleşmeler birçok ülke tarafından imzalanmış ve yayınlanmıştır. $\mathrm{Bu}$ bildiri ve sözleşmelerin asıl amacı toplumların barış ve refah içinde yaşamalarını sağlamaktır. Bu bildiri ve sözleşmeler toplumda yer alan her bireye temel haklarını hatırlatmıştır. 1948 yılında Birleşmiş Milletler Kurulu tarafından İnsan Hakları Evrensel Bildirgesi'nin ilan edilmesi ile uluslararası bir nitelik kazanan insan hakları, 1950 yılında Avrupa İnsan Hakları Sözleşmesi ile devletin gerekliliği olarak kabul edilmiş ve hukuksal bir özellik kazanmıştır (Kepenekçi, 2000). Çocuk hakları ise insan haklarının bir alt boyutudur. Çocuk hakları kavramı makro düzeyde toplumsal, felsefi, ahlaki ve yasal boyutlar içermekte mikro düzeyde ise objektif hukukun çocuklara tanıdığı hak ve sorumlulukların tümünü ifade etmektedir (C1lga, 2001). Çocuk Hakları Sözleşmesi'nde yaşama, gelişme, korunma, bakım ve katılım hakları çerçevesinde çocukların yaşam standartları açıklanmışır. Her çocuğun haklarının farkında olması, haklarını koruması ve diğerlerinin haklarını gözetmesi açısından sözleşmede yer alan haklarının neler olduğunu bilmesi önemlidir. UNICEF (1998)'in raporuna göre erken dönemden itibaren çocuklara bu farkındalığı kazandırmak ailelerin, öğretmenlerin ve içinde bulunduğu 
Leblebici, H., Çeliköz, N. (2017). Prospective teachers' attitudes towards children rights. International Journal of Social Sciences and Education Research, 3(1), 307-318.

toplumun sorumluluğu altındadır. Bu sorumluluk önce çocuğun ebeveynlerine aittir. Çocuk Hakları Sözleşmesi'ni 20-30 Eylül 1990 tarihleri arasında Birleşmiş Milletler Genel Merkezi'nde imzalayan Türkiye, 27 Ocak 1995 tarihli Resmi Gazete ile bu sözleşmeyi iç hukuk kurallarına dönüştürmüştür (Doğan, 2002). Toplumu oluşturan en önemli temel insandır. Çocukların hukuksal açıdan düzenlenen kurallarla korunması insan hak ve hürriyetlerine uygun olarak uygulanması bütün insanlığın iyi yetişmesinde önemli bir yere sahiptir.

Çocuk hakları ile ilgili Türkiye'de yapılan araştırmaların özellikle son yıllarda yapılmış olması çocuk hakları kavramının yeni çalışmalara açık olduğunu göstermektedir. Çetinkaya (1998) öğretmenlerin çocuk haklarına bakışı ile öğrencilerin bakış açılarının benzerlik gösterdiğini belirtmiştir. Öğrenciler yapılan araştırma sonuçlarına göre okul ve ev ortamlarında kendi haklarının öneminden bahsederken öğretmenlerin, öğrencilere oranla ev ve okul ortamlarında çocuk haklarının varlığının daha alt düzeyde olduğunu belirttikleri görülmüştür. Özel okul öğretmenlerinin hakların korunmasına ve önem verilmesine dair daha özverili oldukları ortaya çıkmıştır. Morine (2000), çocukların ve ebeveynlerin çocuk haklarına ve aile ilişkilerine yönelik tutumları algılamalarında ebeveynlerin önemli derecede bakım ve korumadan yana, çocukların ise aile içi kararlarda kendi kendine karar vermeden yana tavır sergilediklerini tespit etmiştir. Kepenekçi (2006), üniversite eğitiminde insan hakları eğitimi almış öğrencilerin çocuk haklarına yönelik tutumları insan hakları dersi almamış öğrencilere kıyasla daha olumlu olduğu savunmaktadir.

Fazlıŏlu (2007), “Çocuk Hakları Sözleşmesinde Yer Alan 'Çocuk Hakları’ konusunda öğretmen ve yöneticilerin çocuk haklarını kavramış olmalarına karşın uygulamalarının istenen düzeyde olmadığı sonucuna ulaşmıştır. Ersoy (2008) ise demokrasinin öğrenilmesi, demokratik ortamlarda demokrasi eğitimi yoluyla mümkün olabileceğini belirtmiştir. Kop ve Tuncel (2010), Türkiye "nin çocuk gerçeği açısından çocuk hakları konusundaki durumunu betimlemiş Türk toplumunda çocuk gerçeğinin, Çocuk Hakları Sözleşmesi ile öngörülen bazı hedeflerin gerisinde olduğunu ifade etmişlerdir. Öncelikle çocuklara, kendi haklarını ögretmek ve benimsetmek için bazı uygulama ve etkinlikler yapılmasını bu konuda hem öğretmenlere hem de kitle iletişim araçlarına büyük rol düştüğünü belirtmişlerdir. Ersoy (2011)'a göre öğrencilerin haklarına ilişkin algıları ve öğrendiği kaynaklar ile karşılaştıkları sorunlar, sosyo-ekonomik düzeye göre farklılaşmaktadır. Ayrıca öğrenciler okulda öğretmenlerin evde ise anne babalarının kendilerine haklarını ögretmelerini beklemektedirler

Tunç (2008), Çocuk Hakları Sözleşmesi’nin eğitim politikalarına yansımaları konusunda Milli Eğitim Bakanlığı uzmanlarının görüşlerini almıştır. Uzmanların baskıcı eğitimden kurtulmak, daha demokratik olmak, kendine güvenen, haklarının bilincinde olan bir nesil yetiştirebilmek için sözleşmede yer alan hakların eğitim politikalarına yansıtılması gerekliliği ve önemi konusunda görüş birliği içerisinde oldukları belirlenmiştir. Fakat eğitim uzmanlarının Çocuk Hakları Sözleşmesi'nin belirlediği yaşamsal, gelişimsel, korunma ve katılım haklarının eğitim politikalarına yansımaları konusunda görüş farklılıkları olduğu ortaya çıkmıştır. Uluç (2008), Türk İlköğretim Sistemi’nde ders programlarının genel açıklamalarında çocuk hakları eğitimi ile uyumlu yaklaşımların görüldügünü ancak bunların kazanımlara ve etkinliklere tam olarak yansımadığı sonucuna ulaşmıştır.

Kepenekçi ve Baydık (2009) çocuk hakları sözleşmesinde geçen ve çocuklara tanınan haklar konusunda çocukların bilgi sahibi olmaları gerekliliğini vurgulayarak bu konuda gerekli bilincin sağlanması için öncelikle ebeveynler ve öğretmenler olmak üzere yetişkinlerin bu konuda eğitim 
Leblebici, H., Çeliköz, N. (2017). Öğretmen adaylarının çocuk haklarına yönelik tutumları. International Journal of Social Sciences and Education Research, 3(1), 307-318.

almalarının gerekliliğinden bahsetmişlerdir. Karaman (1993) özellikle sınıf öğretmenlerinin geneline bakıldığında çocuk hakları konusunda yeterli bilgiye sahip olmadıklarını belirtmiştir. Eğitim kurumları, çocuk haklarının uygulanması ve öğretilmesi için en önemli ve öncelikli kurumlardır. Bu kurumlarda öğretmenlerin çocuk haklarına yönelik farkındalık sahibi olmaları ve demokratik ortamlarda uygulamaya yönelik olarak öğrenenlere kazanım sağlamaları oldukça önemlidir. Bu bağlamda öğretmen adaylarının çocuk haklarını ne kadar biliyor ve benimsiyor oldukları da önemli hale gelmektedir.

\section{Problem cümlesi}

$\mathrm{Bu}$ araştırma, eğitim fakültelerinde lisans öğrenimi gören sınıf öğretmeni ve okul öncesi öğretmen adaylarının çocuk haklarına yönelik tutumlarını belirlemeyi amaçlamaktadır. Bu bağlamda araştırmanın problemini “Öğretmen adaylarının çocuk haklarına yönelik tutumları nasıldır?" sorusu oluşturmaktadır.

\section{Alt problemler:}

1. Öğretmen adaylarının genel olarak çocuk haklarına yönelik tutumları nasıldır?

2. Öğretmen adaylarının çocuk haklarına yönelik tutumları cinsiyetlerine göre farklılık göstermekte midir?

3. Öğretmen adaylarının çocuk haklarına yönelik tutumları bölümlerine göre farklılık göstermekte midir?

4. Öğretmen adaylarının çocuk haklarına yönelik tutumları sahip oldukları kardeş sayısına göre farklıl1k göstermekte midir?

5. Öğretmen adaylarının çocuk haklanı sözleşmesini okuyup-okumama durumlarına göre çocuk haklarına yönelik tutumları farklılık göstermekte midir?

\section{Yöntem}

$\mathrm{Bu}$ araştırmada, öğretmen adaylarının çocuk haklarına yönelik tutumları incelenmektedir. $\mathrm{Bu}$ yüzden araştırma betimsel nitelikte olup tarama modeline dayalı olarak yürütülmüsstür. Tarama modelleri, geçmişte veya günümüzde halen var olan bir durumu, olduğu gibi betimlemeyi amaçlayan araştırma yaklaşımlarıdır. Araştırmaya konu olan olay, birey veya nesne, kendi koşulları içinde ve olduğu gibi tanımlanmaya çalışılır. Onları herhangi bir şekilde değiştirme, etkileme çabası gösterilmez (Karasar, 2010).

\subsection{Evren örneklem}

Araştırmada, öğretmen adaylarının çocuk haklarına yönelik tutumlarının belirlenmesi amaçlamaktadır. Bu amaçla yürütülen araştırmanın çalışma grubu Yıldız Teknik Üniversitesi Eğitim Fakültesi’nde öğrenim gören 130 öğretmen adayı ile İstanbul ili Küçükçekmece ilçesinde bulunan ve bir vakıf üniversitesinde öğrenim gören 126 öğretmen adayı olmak üzere toplam 256 öğretmen adayından oluşmaktadır.

Tablo 1. Cinsiyet dağılımı

\begin{tabular}{lllll}
\hline \multirow{3}{*}{ Cinsiyet } & \multicolumn{2}{c}{ Kadın } & \multicolumn{2}{c}{ Erkek } \\
\cline { 2 - 5 } & $\mathrm{N}$ & $\%$ & $\mathrm{~N}$ & $\%$ \\
\cline { 2 - 5 } & 119 & 46.5 & 137 & 53.5 \\
\hline
\end{tabular}


Leblebici, H., Çeliköz, N. (2017). Prospective teachers' attitudes towards children rights. International Journal of Social Sciences and Education Research, 3(1), 307-318.

Araştırmanın örneklem grubu Tablo 1. de görüldüğü üzere 119'u kadın, 137 si erkek olmak üzere toplam 256 kişiden oluşmaktadır. Öğretmen adayları okul öncesi ve sınıf öğretmenliği bölümlerinden seçilmiştir. Bunun sebebi çocuk hakları kavramı bilincinin erken yaşlarda oluşmaya başladığı okul öncesi ve ilkokul dönemlerindeki öğretmen adaylarının tutumlarını belirlemektir. Araştırmanın verileri 2014-2015 eğitim öğretim y1lı bahar döneminde toplanmıştır. Araştırmada, öğrenim gören öğretmen adaylarının çocuk haklarına yönelik tutumlarının cinsiyet, aday oldukları öğretmenlik branşı, sahip oldukları kardeş sayısı, çocuk hakları sözleşmesini okuyup okumadıkları ve tüm bu değişkenlerin "Çocuk Hakları Tutum Ölçeği”" ile arasındaki ilişkileri incelenmiştir.

\subsection{Veri toplama araçları}

Araştırmada, Karaman Kepenekçi (2006) tarafından geliştirilen 'Çocuk Haklarına Yönelik Tutum Ölçeği' kullanılmıştır. Karaman Kepenekçi (2006) tarafından geliştirilen 'Çocuk Haklarına İlişkin Tutum Ölçeği’ 5'li likert formunda hazırlanmış olup, içeriğinde çocukların yaşamsal, gelişimsel, korunma ve katılım haklarına ilişkin 22 madde bulunmaktadır. Bu ifadeler için “Tamamen Katılıyorum”(5), “Katılıyorum”(4), “Kararsızım”(3), “Katılmıyorum”(2) ve "Tamamen Katılmıyorum”(1) tepki seçenekleri bulunmakta ve puanlanmaktadır. Ölçekteki ifadelerin 19'u olumlu, 3'ü olumsuzdur. Olumsuz ifadelere (2., 14. ve 15. maddeler) verilen tepkiler ters puanlanmaktadır. Puanlama sonucunda ölçekten alınacak en düşük puan 22 ve en yüksek puan ise 110'dur. Karaman Kepenekçi (2006) ölçeğin geçerliğine ve güvenirliğine ilişkin yaptığ çalışma sonucunda, ölçeğin tek faktörlü olduğunu, ölçekteki maddelerin madde toplam korelasyon katsayılarının .32 ile .61 arasında değiştiğini, Cronbach Alpha iç tutarlılık katsayısının 0.85 , yarı test güvenirlik katsayısının ise 0.77 olarak belirlendiğini ifade etmiştir. Bununla birlikte bu araştırmada ayrıca geçerlilik-güvenirlik için bir ön deneme çalışması yapılmıştır. Yapılan doğrulayıcı faktör analizi sonuçlarına göre uyum iyiliği değerlerini düşüren iki madde atılarak 20 maddeye indirilmiştir. Tek faktörlü yapısını koruyan ölçme aracının Doğrulayıcı Faktör Analizi (DFA) sonuçları $\left(x^{2}=604.48, \mathrm{sd}=327 ; \mathrm{RMSEA}=0.076, \mathrm{NFI}=0,91 ; \mathrm{GFI}=0.90, \mathrm{AGFI}=0.88\right.$; $\mathrm{RMR}=0.048$; SRMR=0.049) iyi bir uyumun göstergesi olarak kabul edilmiş ve ölçme aracının tek faktörlü yapısının doğrulandığı şeklinde yorumlanmıştır. 20 maddelik ölçme aracına yapılan Cronbach Alpha güvenirlik sonucu ise 0.88 bulunmuştur.

\subsection{Verilerin analizi}

Çalışma grubunu oluşturan öğretmen adaylarına uygulanan " Çocuk Haklarına Yönelik Tutum Ölçeği'”nden elde edilen verilerin analizinde SPSS 19.0 paket programı kullanılmıştır. Verilerin analizinde izlenen yol ise şu şekildedir:

Örneklemi oluşturan öğretmen adaylarının demografik ve kişisel bilgileri ile ilgili bulgular için frekans analizi uygulanmıştır. Bir yada daha çok değişkene ait değerlerin ya da puanların dağılımına ait özelliklerini betimlemek amacıyla verileri sayı ve yüzde olarak tablolaştırmak için frekans analizi kullanılmaktadır (Büyüköztürk, 2011). Elde edilen bulgular tablolaştırılarak yüzde (\%) ve frekans ( f ) olarak ifade edilmiştir.

Frekans analizi sonrasında, örneklem grubundan elde edilen veriler üzerinde uygun istatistiksel analizleri yapabilmek amacıyla her bir ölçekten elde edilen verilerin normal dağılım gösterip göstermediğini inceleyebilmek için öncelikle verilerin çarpıklık ve basıklık katsayıları ile aritmetik ortalaması, ortancası ve modu incelenmiş, son olarak Kolmogorov-Smirnov Testi ile 
Leblebici, H., Çeliköz, N. (2017). Öğretmen adaylarının çocuk haklarına yönelik tutumları. International Journal of Social Sciences and Education Research, 3(1), 307-318.

de dağılımın ( $>0.091)$ normalliğine karar verilerek çalışma kapsamında parametrik istatistiksel işlemler kullanılmasına karar verilmiştir.

Örneklemi oluşturan öğretmen adaylarından elde edilen verilerin parametrik dağıldığının belirlenmesi sonucunda araştırmanın alt problemlerinin analizinde; iki ilişkisiz örneklemden elde edilen puanların birbirinden anlamlı bir şekilde farklılık gösterip göstermediğini test etmek için bağımsız örneklem t-testi kullanılmıştır. Sayısal gelişmelerle ilgili veriler tablolar haline getirilip yorumlanmış, bağımsız değişkenler arasında anlamlı bir farklılık olup olmadığı $\mathrm{p}=.05$ düzeyinde test edilmiştir (Büyüköztürk, 2011).

\section{Bulgular ve yorum}

Araştırmanın bu bölümünde, örneklem grubuna ait demografik bilgilerin açılanması ve araştırmadan elde edilen verilerin uygun istatistiksel yöntem ile analizi sonucunda ortaya çıkan bulgulara ve bu bulgulara yönelik yorumlara yer verilmiştir. Ayrıca, araştırmaya katılan öğretmen adaylarından elde edilen veriler için öğretmen adaylarının kişisel ve demografik bilgileri ve öğretmenlerin çocuk haklarına yönelik tutumlarına ilişkin alt problemlerin incelenmesi olmak üzere iki ayrı alt başlığa yer verilmiştir.

Araştırmada ölçek formundan elde edilen verilerin analizinde her bir boyuta ilişkin ortalama ve standart sapma değerleri hesaplanmış ve bu değerler her bir boyuta ilişkin tabloda verilmiştir. Ortalama değerlerin daha kolay yorumlanması için aşağıda tabloda verilen puan aralıkları belirlenmiştir.

Tablo 2. Aritmetik ortalamaların değerlendirme aralığ1

\begin{tabular}{ll}
\hline Puan Aralı̆̆ 1 & Yorum \\
\hline $1.00-1.80$ & Hiç Katılmıyorum \\
$1.81-2.60$ & Katılmıyorum \\
$2.61-3.40$ & Kararsızım \\
$3.41-4.20$ & Katılıyorum \\
$4.21-5.00$ & Tamamen Katılıyorum \\
\hline
\end{tabular}

$\mathrm{Bu}$ değerlere göre örneğin katılımcıların bir maddeye ilişkin görüşleri ile ortalama değer 4.40 hesaplandıysa bu maddeye ilişkin görüşlerinin "tamamen katılıyorum" olduğu şeklinde yorumlanmıştır.

Tablo 3. Öğretmen adaylarının çocuk haklarına yönelik genel tutumlarına ilişkin betimsel istatistik sonuçları

\begin{tabular}{cccccc}
\hline $\mathrm{N}$ & Minimum & Maximum & $\mathrm{x}$ & ss & Yorum \\
\hline 256 & 3,10 & 5,00 & 4,66 & 0,36 & $\begin{array}{c}\text { Tamamen } \\
\text { Katiliyorum }\end{array}$ \\
\hline
\end{tabular}

Tablo 3'de katılımcıların çocuk haklarına yönelik tutumlarının ne düzeyde olduğu ve yorumu verilmiştir. Elde edilen bulgulara göre katılımcıların çocuk haklarına yönelik tutumları ortalama puanlarının 4.66 olduğu tespit edilmiştir. Bu bulgu katılımcıların çocuk haklarına yönelik tutumlarının yüksek düzeyde olduğunu göstermektedir. 
Leblebici, H., Çeliköz, N. (2017). Prospective teachers' attitudes towards children rights. International Journal of Social Sciences and Education Research, 3(1), 307-318.

Tablo 4. Cinsiyetlerine göre öğretmen adaylarının çocuk haklarına yönelik tutum puanlarının karşılaştırılması

\begin{tabular}{cccccc}
\hline Cinsiyet & $\mathrm{N}$ & $\mathrm{X}$ & $\mathrm{ss}$ & $\mathrm{t}$ & $\mathrm{p}$ \\
\hline Kadin & 119 & 4,76 & 0,26 & & \\
Erkek & 137 & 4,56 & 0,41 & 4,73 & 0.00 \\
\hline
\end{tabular}

Tablo 4'de görüldüğü gibi, örneklemi oluşturan öğretmen adaylarının Çocuk Haklarına Yönelik Tutum Ölçeği'nden aldıkları puanların, öğretmen adaylarının cinsiyeti değişkenine göre anlamlı bir farklılık gösterip göstermediğini belirlemek amacıyla bağımsız örneklem t testi uygulanmıştır. Elde edilen bulgulara göre, kadın katılımcıların ortalama puanları 4,76 iken erkek katılımcıların ortalama puanı 4,56 olarak tespit edilmiştir. Katılımcı ortalama puanları arasındaki bu fark istatistiksel olarak anlamlı bulunmuştur $(\mathrm{t}=4,73 ; \mathrm{p}<.05)$. Söz konusu farklılık kadın ögretmen adaylarının lehine gerçekleşmiştir.

Tablo 5. Bölümlerine göre öğretmen adaylarının çocuk haklarına yönelik tutumlarının karşıslaştırılması

\begin{tabular}{cccccc}
\hline Bölüm & $\mathrm{N}$ & $\mathrm{x}$ & $\mathrm{ss}$ & $\mathrm{t}$ & $\mathrm{P}$ \\
\hline 1 (Okul Öncesi) & 119 & 4,71 & 0,26 & & \\
2 (Sınıf & 137 & 4,60 & 0,41 & 2,012 & 0.48 \\
Öğretmenliği) & & & & \\
\hline
\end{tabular}

Tablo 5'te, örneklemi oluşturan öğretmen adaylarının Çocuk Haklarına Yönelik Tutum Ölçeği’nden aldıkları puanların öğretmen adaylarının bölüm değişkenine göre anlamlı bir farklılık gösterip göstermediğini belirlemek amacıyla bağımsız örneklem $t$ testi uygulanmıştır. Elde edilen bulgulara göre, okul öncesi katılımcıların ortalama puanları 4,71 iken sınıf öğretmeni katılımcıların ortalama puanı 4,60 olarak tespit edilmiştir. Katılımcı ortalama puanları arasındaki bu fark istatistiksel olarak anlamlı bulunmamıştır $(t=2,01 ; \mathrm{p}>.05)$. Diğer bir ifade ile öğretmen adaylarının bölümlerine göre çocuk haklarına yönelik tutumlarında bir farklılık yoktur.

Tablo 6. Kardeş sayılarına göre öğretmen adaylarının çocuk haklarına yönelik tutumlarının karşılaştırılması

\begin{tabular}{cccccc}
\hline Kardeş & $\mathrm{N}$ & $\mathrm{x}$ & $\mathrm{ss}$ & $\mathrm{t}$ & $\mathrm{p}$ \\
\hline 2 ve Daha Az & 121 & 4,54 & 0,41 & \multirow{2}{*}{3,21} & \multirow{2}{*}{0.02} \\
3 ve Daha Fazla & 135 & 4,68 & 0,38 & & \\
\hline
\end{tabular}

Tablo 6'da görüldüğü gibi, örneklemi oluşturan öğretmen adaylarının Çocuk Haklarına Yönelik Tutum Ölçeği'nden aldıkları puanların öğretmen adaylarının kardeş sayısı değişkenine göre anlamlı bir farklılık gösterip göstermediğini belirlemek amacıyla bağımsız örneklem t testi uygulanmıştır. Elde edilen bulgulara göre, 2 ve daha az kardeş sayısı olan katılımcıların ortalama puanları 4,54 iken kardeş sayısı 3 ve daha fazla olan katılımcıların ortalama puanı 4,68 olarak tespit edilmiştir. Katılımcı ortalama puanları arasındaki bu fark istatistiksel olarak anlamlı bulunmuştur $(\mathrm{t}=3,21 ; \mathrm{p}<.05)$. Söz konusu farklılık kardeş sayısı 3 ve daha fazla olan öğretmen adaylarının lehine gerçekleşmiştir.

Tablo 7. Öğretmen adaylarının çocuk hakları sözleşmesini okuyup-okumama durumlarına göre çocuk haklarına yönelik tutumlarının karşılaştırılması

\begin{tabular}{cccccc} 
ÇHS & $\mathrm{N}$ & $\mathrm{X}$ & ss & $\mathrm{t}$ & $\mathrm{p}$ \\
\hline evet & 112 & 4,70 & 0,32 & 1,59 & 0,113 \\
hayır & 144 & 4,63 & 0,39 & 1,59 & \\
\hline
\end{tabular}


Leblebici, H., Çeliköz, N. (2017). Öğretmen adaylarının çocuk haklarına yönelik tutumları. International Journal of Social Sciences and Education Research, 3(1), 307-318.

Tablo 7'de , örneklemi oluşturan öğretmen adaylarının Çocuk Haklarına Yönelik Tutum Ölçeği’nden aldıkları puanların öğretmen adaylarının Çocuk Hakları Sözleşmesi'ni okuyupokumama durumları değişkenine göre anlamlı bir farklılık gösterip göstermediğini belirlemek amacıyla bağımsız örneklem t testi uygulanmıştır. Elde edilen bulgulara göre, Çocuk Hakları Sözleşmesi'ni okuyan katılımcıların ortalama puanları 4,70 iken, Çocuk Hakları Sözleşmesi'ni okumayan katılımcıların ortalama puanı 4,63 olarak tespit edilmiştir. Katılımcı ortalama puanları arasındaki bu fark istatistiksel olarak anlamlı bulunmamıştır $(\mathrm{t}=1.59 ; \mathrm{p}>.05)$. Diğer bir ifade ile öğretmen adaylarının çocuk hakları sözleşmesini okuyup-okumama durumlarına göre farklılık yoktur.

\section{Tartışma ve Sonuç}

Araştırma sonucunda öğretmen adaylarının genel olarak çocuk haklarına yönelik tutumlarının yüksek olduğu görülmektedir. Ekici (2014) “Öğretmen Adaylarının Çocuk Haklarına Yönelik Tutumlarının Bazı Değişkenlere Göre İncelenmesi” başlıklı araştırmasında pedagojik formasyon programında öğrenim görmekte olan öğretmen adayları ile benzer bulgulara ulaşmıştır. Araştırma sonuçları, öğretmen adaylarının meslek seçimlerini yaparken bilinçli olarak bu mesleği seçmeleri ile ilişkilendirilmiştir. Bu bağlamda öğretmen adaylarının bilinçli olarak öğretmenlik mesleğini seçmelerinde çocuklara karşı duyarlı olmaları ile çocuk haklarına yönelik tutumlarının yüksek olması arasında pozitif yönde bir bağlantı olduğu yorumuna ulaşılabilir.

Öğretmen adaylarının çocuk haklarına yönelik tutumları, cinsiyet değişkenine göre de farklılaşmaktadır. Bu bulgudan hareketle kadın öğretmen adaylarının çocuk haklarına yönelik tutumları erkek öğretmen adaylarına göre daha olumludur. Kepenekçi (2006) "Türkiye'de Üniversite Öğrencilerinin Çocuk Haklarına Yönelik Tutumları” başlıklı araştırmasında eğitim bilimleri fakültesinde öğrenim gören kız ve erkek öğrencilerden, kız öğrencilerin çocuk haklarına yönelik tutumlarının daha olumlu olduklarını ifade etmiştir. Değirmenci (2011) "Öğretmen Adaylarının Çocuk Haklarına İlişkin Tutumlarının İncelenmesi” nde ise yine kadın öğretmen adaylarının, erkek ögretmen adaylarına göre çocuk hakları ile ilgili olumlu tutumlara sahip oldukları sonucuna ulaşmıştır. Kepenekçi ve Baydık (2009) yaptıkları araştırma sonucunda ise cinsiyet değişkeninin öğretmen adayları üzerinde çocuk haklarına yönelik tutumları üzerinde bir etkisi olmadığı sonucuna ulaşmışlardır. İlgili araştırmaların sonuçları değerlendirildiğinde cinsiyet değişkenine yönelik birbirinden farklı sonuçlara ulaşıldığı ortaya çıkmaktadır. Buradan hareketle öğretmen adaylarının çocuk haklarına yönelik tutumlarının temel belirleyicisinin cinsiyet olmadığ 1 yorumu yapılabilir.

Araştırmada ayrıca öğretmen adaylarının bölümlerine göre sınıf öğretmenliği ya da okul öncesi öğretmenliği bölümlerinde aldıkları eğitim ile çocuk haklarına yönelik tutumlarının farklılık göstermediği de ortaya çıkmıştır. Kepenekçi ve Baydık (2009) "Zihin Engelliler Öğretmen Adaylarının Çocuk Haklarına İlişkin Tutumları"nı belirlemeye yönelik bir araştırma yapmışlar ve bu araştırma sonucuçlarına göre de farklı programlarda öğrenim gören öğretmen adaylarının tutumlarının farklılaşmadığı görülmüştür. Benzer bulgular Değirmenci (2011)'in araştırmasında da okul öncesi öğretmen adaylarının çocuk haklarına yönelik tutumlarının diğer bölümlere devam eden öğretmen adaylarına göre daha olumlu düzeyde olduğu görülmektedir. Öğretmen adaylarının bölümlerine göre çocuk haklarına yönelik tutumlarının farklılaşmamasının sebebi olarak mesleki yatkınlık gösterilebilir. Ayrıca lisans programlarında bölümlere göre hazırlanan ders içeriklerinde çocuk haklarına yönelik kazanımların yer alması ve mezun olduktan 
Leblebici, H., Çeliköz, N. (2017). Prospective teachers' attitudes towards children rights. International Journal of Social Sciences and Education Research, 3(1), 307-318.

sonra öğretmenlik mesleğini yapma durumlarına göre çocuk ve çocuk haklarına yönelik duyarlılık ile de açıklanabilir.

Öğretmen adaylarından kardeş sayısı 3 ve daha fazla olanların çocuk haklarına yönelik tutumlarının daha yüksek olduğu araştırma sonuçlarına göre ortaya çıkmaktadır. Aile içerisinde kardeş sayısı ile artan aile nüfusunda; eşitlik, demokratik olma gibi temel insan hakları daha fazla yaşanmaktadır. bu durum da aile içerisinde doğal yollarla çocuk haklarına yansımaktadır. Doğan, Torun ve Akgün (2014) "Okul Öncesi Öğretmen Adaylarının Çocuk Haklarına İlişkin Tututmlarının Çeşitli Değiş̧kenlere Göre İncelenmesi” başlıklı araştırmalarında kardeş sayısı fazla olan öğretmen adaylarının çocuk haklarına yönelik tutumlarının yüksek olduğu ile ilgili bulgulara ulaşmıştır. Bu bulgu da araştırmada ortaya çıkan sonucu desteklemektedir.

Çocuk Hakları Sözleşmesi’nin 42. maddesi gereğince çocuk haklarının yetişkinler ve çocuklar tarafından öğrenilmesi ve yaygınlaştırılması için öğretmen adaylarına ve öğretmenlere, hatta çocuklarla ilgili tüm alanlarda çalışanlara bu eğitimin verilmesi gerekliliği ortaya çıkmaktadır. Uçuş (2009) "Çocuk Hakları Sözleşmesi'nin İlköğretim Programlarındaki Yeri ve Sözleşmeye Yönelik Öğretmenlerin ve Okul Yöneticilerinin Görüşleri” çalışmasında ilgili ders öğretmenleri, sınıf öğretmenleri ve okul yöneticileri ile görüşerek bu görüşü destekleyen bulgulara ulaşmıştır.

Öğretmen adaylarından, Çocuk Hakları Sözleşmesini daha önce okuyan öğretmen adaylarının çocuk haklarına yönelik tutumlarının daha yüksek olduğu görülmektedir. Bu noktadan hareketle lisans düzeyinde aldıkları derslerde çocuk hakları ile ilgili içerik öğrenimi almış olan öğretmen adaylarının çocuk haklarına yönelik tutumları daha yüksek düzeydedir. Covell ve Howe (1999)'un çocuk hakları ile ilgili farkındalığın arttırılması için yapılan çalışmaların çocuk haklarına yönelik tutumları olumlu yönde etkilediğine yönelik bulguları ile Karaman ve Kepenekçi (2006)'nin insan hakları ve çocuk haklarına yönelik ders alan lisans öğrencilerinin bu dersleri almayan lisans öğrencilerine göre tutumlarının daha yüksek düzeyde olduğu sonuçları bu çalışma ile örtüşmektedir. Değirmenci (2011) öğretmen adaylarının çocuk haklarına ilişkin görüşlerini incelediği araştırmasında okul öncesi eğitimi programına devam eden öğretmen adaylarının aldıkları ders içeriği sebebiyle, diğer bölümlerde öğrenim gören öğretmen adaylarına göre daha olumlu tutuma sahip oldukları sonucuna ulaşmıştır. Çocuk Hakları Sözleşmesi'nde yer alan bütün hükümlerin herkes tarafından öğrenilmesi öngörülmektedir. Öğretmen adaylarının aldıkları ders içerikleri ile çocuk haklarına yönelik tutumlarının yüksek olması arasında çocuk haklarına yönelik ders içeriklerinin öğretmen adaylarının farkındalıklarını arttırdığı yönünde olumlu bir yargiya varılabilir.

\section{5. Öneriler}

Bu çalışma okul öncesi ve sınıf öğretmenliğinde öğrenim görmekte olan öğretmen adayları ile yapılmıştır. Başka bir çalışma, diğer branşlarda öğrenim görmekte olan öğretmen adayları için de yapılabilir. Bununla birlikte görev yapmakta olan sınıf öğretmenleri ile farklı çalışmalar yapılabilir. Ayrıca araştırmalarda uzman desteği de alınıp veli boyutu ve öğrenci boyutu da eklenebilir. Bu çalışma, İstanbul ili ile sınırlandırılmıştır. Başka bir çalışma geniş çapta yapılabilir. Çalışmada ele alınan değişkenlerin dışında, başka bir çalışmada farklı değişkenler üzerinde de araştırmalar yapılabilir. Nicel araştırma yönteminin kullanıldığı bu çalışmanın dışında, nitel araştırmalar ile de daha derinlemesine incelemeler yapılabilir. Okullarda; bireylerin demokrasi ve çocuk haklarının gelişimi, sürekliliği ve demokrasiye istenen ölçüde katkı sağlayabilmeleri için demokrasi ve haklara gereken önemi verebilen demokrat öğretmenlere 
Leblebici, H., Çeliköz, N. (2017). Öğretmen adaylarının çocuk haklarına yönelik tutumları. International Journal of Social Sciences and Education Research, 3(1), 307-318.

gerek vardır. Dolayısıyla öğretmen yetiştiren yükseköğrenim kurumlarından öğretmen adaylarının gerekli donanım ve bilgi ile mezun olabilmeleri için bu konuyla ilgili eğitim verilebilir.

\section{Kaynakça}

Büyüköztürk, Ș. (2011). Sosyal bilimler için veri analizi elkitabı. Ankara: Pegem Akademi.

Cılga, İ. (2001). Demokrasi ve insan hakları kültürü ve çocuk hakları. Milli Eğitim Dergisi, 151 (3),69-73.

Covell, K., Howe, R. B. (1999). The impact of children's rights education: A Canadian study. The International Journal of Children's Rights, 7, 171-183.

Çetinkaya, N. (1998). Öğretmenlerin ve ögrencilerin çocuk haklarına bakışının değerlendirilmesi (Yayımlanmamış Yüksek Lisans Tezi). Marmara Üniversitesi Eğitim Bilimleri Enstitüsü, İstanbul.

Değirmenci, T. (2011). Öğretmen adaylarının çocuk haklarına ilişkin tutumlarının incelenmesi, XX. Eğitim Bilimleri Kurultayı, Burdur: Mehmet Akif Ersoy Üniversitesi.

Doğan, İ. (2000). Akıllı kü̧̧ük çocuk kültürü ve çocuk hakları üzerine sosyo-kültürel bir inceleme. İstanbul: Sistem.

Doğan, İ. (2001). Çocuk hakları açısından Türkiye'de çocuk olgusu. Milli Eğitim Dergisi 151 (3), 54-64.

Doğan, İ. (2002). Modern toplumda vatandaşlık demokrasi ve insan haklarl. Ankara: Pegem.

Doğan, Y., Torun, F., \& Akgün, H. (2014). Okul öncesi öğretmen adaylarının çocuk haklarına ilişkin tutumlarının çeşitli değişkenlere göre incelenmesi. International Journal of human Sciences, 11(2), 503516. doi: $10.14687 /$ ijhs.v11i2.2998

Ekici, Y. F. (2014). Öğretmen adaylarının çocuk haklarına yönelik tutumlarının bazı değişkenlere göre incelenmesi. Akademik Sosyal Araştırmalar Dergisi, 8, 66-77.

Erden, M. (2007). Eğitim bilimlerine giriş, Ankara: Arkadaş Yayınevi.

Ergün, M. (1997). Eğitim sosyolojisine giriş, Ankara: Ocak Yayınları.

Ersoy, A.F. (2008). Çocuk haklarına ilişkin temel kavramlar ve çocuk hakları sözleşmesi- okul öncesinde demokrasi eğitimi ve çocuk hakları, (Ed.) Handan Deveci, Anadolu Üniversitesi Açıköğretim Fakültesi Yayını, 1821, 944, Eskişehir: Anadolu Üniversitesi.

Ersoy, A. F. (2011). İlkögretim ögrencilerinin çocuk haklarına ilişkin algıları, İlköğretim Online, 10, (1), 20-39. (http://ilkogretimonline.org.tr/vol10say1.html adresinden 15.06.2016 tarihinde erişilmiştir).

Fazlığlu, Z. (2007). Çocuk hakları sözleşmesinde yer alan 'çocuk hakları' konusunda ögretmenlerin ve yöneticilerin bilinç düzeyleri (Yayımlanmamış Yüksek Lisans Tezi). Yeditepe Üniversitesi Sosyal Bilimler Enstitüsü, İstanbul.

Gözütok, F. D. (1997). Öğretmenlerin demokratik tutumları, Ankara: Türk Demokrasi Vakfi Yayınları.

Ilgar, L. (2000). Eğitim yönetimi okul yönetimi sinıf yönetimi, İstanbul: Betaş Yayınları.

İnan, A. (1968). Çocuk hukuku, İstanbul: Ankara Üniversitesi.

Karasar, N. (2010). Bilimsel araştırma yöntemi. Ankara: Nobel.

Karaman, Y. (1993). İlkokul ögretmenlerinin gözlemlerine göre çocukların aileleri tarafindan istismarı ve ihmali. Yayınlanmamış yüksek lisans tezi, Hacettepe Üniversitesi, Ankara.

Kepenekçi, Y.K. (2000). İnsan hakları eğitimi. Ankara: Anı.

Kepenekçi, Y.K. (2006). A Study of university students' attitudes towards children's rights in Turkey. The International Journal of Children's Rights, 14, 307-319.

Kepenekçi, Y. K., Baydık, B. (2009). Zihin engelliler öğretmen adaylarının çocuk haklarına ilişkin tutumları. Ankara Üniversitesi Ĕgitim Bilimleri Dergisi, 42(1), 329-350.

Kop,Y. ve Tuncel, G. (2010). Sosyal bilgiler ögrretmenlerinin çocuk haklarını algılamaları. 
Leblebici, H., Çeliköz, N. (2017). Prospective teachers' attitudes towards children rights. International Journal of Social Sciences and Education Research, 3(1), 307-318.

(http://eku.comu.edu.tr/index/6/1/ykop_gtuncel.pdf adresinden 25.11.2014 tarihinde erişilmiştir).

Morine, S.J. (2000). Children "s and parents" attitudes towards children "s rights and perceptions of family relationship (Unpublished Master Thesis). Toronto University. Toronto, Canada.

Selvi, K. (2003). Illköğretim programlarında demokrasi ve insan hakları eğitimi, Ankara: 12. Eğitim Bilimleri Kongresi.

Tunç Çakır, D. (2008). Çocuk hakları sözleşmesinin eğitim politikalarına yansımaları konusunda millî eğitim bakanlı̆̆ uzmanlarının görüşsleri (Yayınlanmamış yüksek lisans tezi). Ankara Üniversitesi Eğitim Bilimleri Enstitüsü, Ankara.

Uçuş, Ş. (2009). Çocuk Hakları Sözleşmesi'nin ilköğretim programlarındaki yeri ve sözleşmeye yönelik ögretmenlerin ve okul yöneticilerinin görüşleri, Hacettepe Üniversitesi Sosyal Bilimler Enstitüsü.

Uluç, Ö. F. (2008). İlköğretim programlarında çocuk hakları (Yayınlanmamış Doktora Tezi). Ankara Üniversitesi Sosyal Bilimler Enstitüsü, Ankara.

UNICEF (1998). Çocuk haklarına dair sözleşme uygulama elkitabı. Ankara: Ajans Türk Basın ve Basım A.Ş.

\section{Extended abstract in English}

Education is a process which includes not only individuals but also the society. Therefore, individuals grown up with concepts such as democracy, human rights or children rights contribute to shaping the society for future generations. Democratic thoughts and behaviours in accordance with democratic thinking are not innate. They are matters of education. (Yeşil, 2002). Therefore, education has a significant role in democracy. Likewise, democracy is so cructial in education. The attitude of the teachers within and outside the classroom environment has an important effect on children.Thus, to be able to develop a form of democtaric society, it is necessary to identify whether teachers have democtaric values or not. Educational institutions are the primary places to practise and teach children rights. In such institutions teachers must be aware of children rights and they must practise them in democratic environments to aim for students' acqusition of the knowledge of what children rights are. In such a context, it is important to determine knowledge level of prospective teachers about children rights and their internalization. According to the Article 42 of the UN Convention on the Rights of the Child, children rights must be learned and promoted by both children and adults. Therefore, teachers, prospective teachers and those working in all other fields concerning children must be trained on this issue.

\section{Problem statement}

This study aims to identify the attitudes of prospective elementry school teachers and preschool teachers towards children rights. The research question of the study is 'What are the attitudes of prospective class teachers and preschool teachers towards children rights?'

Sub-questions:

1. What are the general attitudes of prospective teachers on children rights?

2. Is there a significant gender difference between the attitudes of prospective teachers towards children rights?

3. Is there a significant difference between attitudes of prospective teachers from different departments?

4. Is there a significant difference between attitudes of prospective teachers with different number of siblings?

5. Is there a significant difference between attitudes of prospective teachers who have read 
Leblebici, H., Çeliköz, N. (2017). Öğretmen adaylarının çocuk haklarına yönelik tutumları. International Journal of Social Sciences and Education Research, 3(1), 307-318.

UN Convention on the Rights of the Child and those who haven't?

Method

In this study, prospective teachers' attitudes towards children rights were examined. A descriptive survey method was employed. In the study it is aimed to identify the attitudes of prospective teachers towards children rights. The participants of the study are 130 prospective teachers studying in the Education Faculty of Y1ldız Technical University and 126 prospective teachers studying in one of the foundation universities in Küçükçekmece, Istanbul. There were 256 participants, 119 of whom were women, while 137 were men. Prospective teachers were chosen from departments of education faculties training elementary school teachers and preschool teachers. The concept of children rights starts to be formed in early childhood. Therefore, it is important to identify the attitudes of prospective teachers who teach children at this stage. The data was collected during the spring term of the 2014-2015 academic year. In the study, participants' attitudes towards children rights, their gender, teaching branch, number of siblings, whether they had read UN Convention on the Rights of the Child and the relationship between all these variables and 'Children Rights Attitude Scale' were analysed. In the study a 5-point Likert type 'Children Rights Attitude Scale' developed by Karaman Kepenekçi (2006) was used. It included 22 items concerning children's survival, developmental, protection and participation rights. The lowest score that can be obtained in the scale is 22 , while the highest is 110 .

Discussion and results

It is found out that the scores of prospective teachers' attitudes towards children rights were quite high. The results are associated with the participants consious decision to select the respective department. Therefore, it can be put forward that there is a positive corelation between the participants consious decision to select teaching career and their sensitivitiy to children and their high attitudes towards children rights.

There is a significant gender difference between prospective teachers' attitudes towards children rights. The results show that women participants have more positive attitudes than men. However, when the previous studies in the literature are analyzed, it can be seen that the results related with this variable are not consistent (Kepenekçi,2006; Değirmenci 2011; Kepenekçi and Baydik, 2009). Therefore, it can be stated that gender cannot be the main determiner of the prospective teachers' attitude towards children rights. It was also identified that there is no significant difference between the attitudes of prospective teachers studying at different departments. The reason for that can be professional inclination. Another result obtained in the study is that prospective teachers with 3 or more siblings have more positive attitudes towards children rights. When the number of family members increase, basic human rights such as equality or democracy are needed to be practised more often. This naturally reflects on the practise of children rights in the family. The results show that prospective teachers who have read UN Convention on the Rights of the Child have more positive attitudes towards children rights. Prospective teachers who studied UN Convention on the Rights of the Child within the content of their undergraduate courses have higher attitudes towards children rights. Course contents concerning children rights increase the children rights awareness of prospective teachers. It is suggested that all the articles in the UN Convention on the Rights of the Child must be learned by every citizen. 